\title{
Moral Values in Oral Tradition Bekesah Puspakrama at the Sasak Community in the West Nusa Tenggara (A Structural and Semiotic Review)
}

\author{
Ahmad Turmuzi ${ }^{1 *}$, E. Emzir², Ninuk Lustyantie ${ }^{2}$ \\ ${ }^{1}$ Universitas Nahdlatul Wathan Mataram, Indonesia, Universitas Negeri Jakarta, Indonesia \\ Corresponding Author: Ahmad Turmuzi, E-mail: ahmadturmuzi.unw@gmail.com
}

\section{ARTICLE INFO}

Article history

Received: February 19, 2018

Accepted: April 29, 2018

Published: June 30, 2018

Volume: 9 Issue: 3

Advance access: May 2018

Conflicts of interest: None

Funding: None

\author{
Key words: \\ Moral Values, \\ Oral Tradition, \\ Bekesah Puspakrama, \\ Sasak Community, \\ Structural Approach, \\ Semiotic Approach
}

\begin{abstract}
This study aims to gain a deep understanding in detail in accordance with the research focus on "Moral Values in Oral Tradition of Bekesah Puspakrama at the Sasak Community in the West Nusa Tenggara". This research is not bound by the place because this research is library research. The approach used is qualitative, structural and semiotic approach design with content analysis technique. As a whole the text on Bekesah Puspakrama script consists of 533 verses of song and 152 pages. The researchers found 230 verses of song containing moral values according to sub-focus. Oral tradition is a cultural heritage of a society of previous generations that still exist today and become an identity for the community. The oral tradition of Bekesah Puspakrama has a position and serves as a system of social protection and control, ritual and cultural identity, as well as education and instruction for the Sasak community. The implications and targets aimed at this research have an impact on Indonesian language education and Indonesian literary majors, especially on the teaching of oral literature and oral tradition, especially those related to the content of values in the manuscript. Furthermore, it is expected as one of the alternative teaching materials and can be used as a reference in analyzing other literary works.
\end{abstract}

\section{INTRODUCTION}

Indonesia is a unitary state built on the basis of cultural and ethnic diversity, in accordance with the motto of Bhinneka Tunggal Ika. In addition to abundant natural resources, cultural and ethnic diversity is one of the endowments as a source of cultural richness of the Indonesian nation. Speaking of the Indonesia, then we are also talking about the tribes in it. For example the Minang, Batak, Javanese, Sundanese, Balinese, Sasak, Buginese, Mandar, Dayak and many other ethnic groups. This diversity is accompanied also by differences in the diversity of languages and other traditions.

We realize and understand that language is generally a capability that a person possesses naturally after socializing with his environment since he was born. Language serves as a communication tool and this is the most basic thing, because to express the various ideas, wishes, expectations, feelings that exist in the mind in the communication interaction both orally and in writing. The function of language as a means of communication has to do with the society, culture, and mind of its speakers even with the world in general, there is a connection between human language, society, culture, and the mind (Duranti, 1997: 65).The phenomenon of language, either individually or in groups, in a society is often reflected in traditional cultural events and cultural activities. Cultural activities and custom traditions that live and thrive in the midst of society orally are as diverse as; tale reading, marriage speeches, spells, fairy tales, rhymes, sax, and sacrificial offerings that are considered so sacred. All that is science and knowledge, in addition to being an identity.

Concepts and philosophy in knowing identity until knowing a culture and traditions of society is very important and valuable. Understanding the diverse perspectives of a community group and the concept of values and the philosophy of life of a community group, especially in the multicultural country of Indonesia, has become the main capital of national unity and unity. A society's customs and traditions cannot be interfered by traditions of other groups, especially external cultures, due to belief in the concept of life, values in different customs. In addition, the tradition is a legacy of its predecessor, so that each individual within the community tradition group is obliged to preserve it, especially the subsequent generations in the various joints of life. Folklore is grouped into oral, partial oral, and material. In oral folklore most of the material is oral and usually has a tradition of oral narrative (Emzir \& Saefur, 2015: 228). 
A society's customs and traditions cannot be interfered by traditions of other groups, especially outside cultures, because of the belief in the concept of life, the values in different customs. Bekesah Puspakrama is used by the Sasak community on events or activities related to their lives as a tradition and their beliefs from generation to generation, in the customary event such as; thanks giving, shaving, pilgrimage of old graves, thanks giving of heritage objects, cultivated crops, harvest, thanks giving for a person or spouse that is barren to be given a child. Bekesah itself in Sasak means storytelling, where the purpose is to explain moral values, values of education, struggle, history and philosophy of life for Sasak people as individuals and human beings in living life according to their environment, both physically and psychologically. In addition, the oral tradition of Bekesah in Sasak society contains about prayer and hope, advice, spirit of struggle and heroism that has the meaning of local wisdom in Indonesia.

Oral tradition Bekesah generally implemented in two ways, especially in the process of presentation, which can be seen and witnessed by the public openly. For example; 1)At a traditional Sasak wedding ceremony by a traditional figure in marriage (pembayun), 2) The ritual ceremony of the indigenous house (Bale Belek), the heirlooms, and the tombs that the Sasak people sanctified by the so-called traditional leaders (Pemangku). 3) Religious ceremony of tale reading (bekayat).The special oral tradition of Bekesah is more personal or attended only by a few people, a group that can be trusted to witness it, the presentation process is done in private. For example, 1) ritual ceremonies of supernatural powers (kedikjayaan) especially for Sasak youths, 2) ritual ceremonies of knowledge such as rituals on traditional midwife (belian) for knowledge of Sasak girls, 3) the presentation ritual of Babad/ancestral gene and the reading of the book of tarekat (takepan).

It implies a description of the main problem descriptions of oral traditions in the Sasak community to be studied, understood, and studied as part of the knowledge of Indonesia's diverse cultural diversity. Particularly in the oral tradition of Bekesah Puspakrama that is very unique, the uniqueness with the values contained therein, for example; educational values, cultural values, moral values, and art values.

The formulation of the problem in this research is 1). How are the moral values in the oral tradition Bekesah Puspakrama? 2). How are the moral values in the oral tradition of Bekesah Puspakrama in terms of structural aspects? and 3). How are the moral values in the oral tradition of Bekesah Puspakrama viewed from the semiotic aspect? While the purpose of the study is to know and understand in depth the values contained in the text Bekesah Puspakrama is very sacred to the Sasak community in West Nusa Tenggara. Thus implied a description of the main problem description of oral tradition on the society Sasak is very important to be studied, understood and studied as part of the knowledge about the richness of the culture in Indonesia, especially the oral tradition Bekesah Puspakrama very own uniqueness, uniqueness with the values contained therein, for example; educational values, cultural values, and moral values and art values.

\section{LITERATURE REVIEW}

\section{Bekesah as the Oral Tradition}

Oral tradition or oral literature in theories has diverse views, sometimes what differences are intended. This is highly dependent on the cultural and cultural systems of a society, affecting the forms and types included in the literary texts. Similarly, oral literature and oral tradition, besides being bound by the characteristics of its traditions, are also features of structural texts that are bound by cultural symbols as well. Therefore, every oral tradition and oral literature is bound by the culture of society where the oral tradition and the oral literature were born.

The importance of understanding oral literature in a community group and its various functions in fact contains many systems of values, customs and rules of legal norms that subsequently become customs and traditions. It can be concluded that tradition is oral habits of the community in carrying out and inheriting customs that are considered sacred, while oral literature is an effort how to convey the tradition of adat delivered orally with ethics, aesthetics, and oral systematics in accordance with traditions that have inherited. In the Sasak community in West Nusa Tenggara there are various types of oral traditions and types of oral literary texts one of which is Bekesah. Bekesah in Indonesian is equated by the author with the meaning of "telling" or telling a story. Bekesah is a process of a series of events in the form of communication conveyed in the daily life of the local community by involving elements of philosophy, history, traditions of customs, and distinctive arts as a symbol of regionalism in the Sasak community in West Nusa Tenggara.

The oral tradition of Bekesah in the sasak community is used in the types of customary activities such as; 1) at the ceremony of traditional Sasak wedding ceremony by a traditional figure in marriage (pembayun), 2) religious ceremony of tale reading (bekayat), 3) ritual presentation of Babad or ancestral gene (takepan), and 4) ritual ceremony of thanks giving (selamatan) custom house (Bale Belek), heirlooms, and graves sown by the Sasak people by the so-called traditional leaders (Pemangku), as well as the presentation of other celebration rituals.

Thus, the authors conclude that oral traditions differ from oral literature but oral literature cannot be separated from oral tradition as a source of oral literary studies. Oral tradition is all the customary activities, religion and traditions of a community delivered orally. While oral literature is the result of the author's imagination to convey his message by giving priority to the values of teaching by giving priority to the aesthetic element.

\section{Terminology of Oral Tradition}

Speaking of oral tradition certainly cannot be separated from the habits of society, including literary works, especially oral literature. Folklore is a term closely related to it. The difference is the scope and in-depth study, especially in the context of the study. Oral tradition parallels oral literature that is part of folklore. 
Folk is a group of people with physical, social and cultural identifiers, so that it can be distinguished from other groups (Alan Dundes in Danandjaya, 2015: 63). Folklore can be interpreted as the identification of a group of people who have characteristics, social, and culture so that can be distinguished from other social groups. The characteristics of the identifier, among others, in the form of customs, forms of trace, art, language, knowledge, and forms of belief or religion. And all that is that they have a tradition, the culture they have inherited from generation to generation, which they have recognized as belonging together. Moreover, that the consciousness of group identity into a tradition is part of the goal as a manifestation of respect and preservation of its own group traditions including oral literature used in oral tradition.

\section{Characteristics of Bekesah Puspakrama}

Bekesah Puspakrama is a script used by the Sasak community for ritual medication activities in pregnant women, newborns, and other celebrations and prayers of salvation by using certain patterns according to the tradition received in the inheritance process. The character possessed by the oral tradition of Bekesah Puspakrama, among others; first, in the process of reading the text consists of three people with different functions, the first reader is as a reader palm or manuscript, the second reader as a translator in the common Sasak language and the third reader in the Indonesian language. Secondly, Bekesah Puspakrama in its delivery (oral) has an intonation that is sung. Third, the process of ritual activities there are preparations by presenting offerings in the form of typical dishes, beverages, fruits and objects containing mystical elements.

\section{Values}

In general, values are an individual's assessment of a life in society when responding to various problems. In addition, the value is learned to answer the problems faced by an individual. Rahmat explains that, value is an abstract (Rahmat, 2013: 155). Whereas in encyclopedia of philosophy explained that axiology equated with value and valuation that consist of three forms among others:

1) Value as an abstract noun. In a narrow sense; something good, interesting and good. As in the broad sense, in the form; duty, truth, and holiness.

2) Values as concrete nouns, for example when we say a value or values, are often used to refer to something valuable, such as its value, and the value system.

3) Values are also often used as verbs in the expression of judging and rating (Edwards, 2002: 77).

Can be interpreted that the value is a measure of something that is abstract but can be read by a person through the ways of thinking, or way of view, both individually and in accordance with the way a group thinks in accordance with a deal worthy or unworthy, good or bad, and true or wrong. So that the meaning and standard value of each individual, different groups, tribes and nations have different but also have similarities, even similarities in giving the status of the measure of something and the thing intended.

\section{Morality}

That morality, first and foremost, is a matter of reason, which is morally right to do in any sphere, determined by the best reasons available to do so. (Rachels, 2004: 35). Furthermore, morality is a characteristic of humans not found in other creatures, morality in the human being is the awareness of good and bad (Djojosuroto, 2006: 12). several layers of literary works, among other layers called metaphysical properties, which are layers that allow contemplation of the philosophical meaning of a literature. The majesty, sanctity, and awesomeness of a literary work, for example causes us to be interested in thinking about it (Ingarden in Suryani \& Elis, 2012: 20).

It is concluded that morality is a habit that becomes the standard of eligibility, propriety to measure the value of a person or group of people in accordance with the culture. In a literary work written by the author aims to, inter alia, offer an idealized life model. Moral in literary works can be viewed as a command or message. Moral values are so vast, the word moral always refers to either bad man. Thus the moral aspect is all aspects concerning the good of an action. In this case concerning attitudes, rights and obligations, morals, and manners, among others; 1) Human Relations with Creator, 2) Human Relations with Nature, 3) Human Relations with Man, 4) Human Relations with Nations and Countries.

\section{Methodology}

This study has a main goal that is tailored to the focus is to obtain a detailed understanding of the depth on "Moral Values in Oral Tradition of Bekesah Puspakrama at the Sasak Community in the West Nusa Tenggara" as follow.

The objectives of the study according to sub-focus in detail as follows;

1) Moral values in the oral tradition of Bekesah Puspakrama,

2) Moral values in the oral tradition of Bekesah Puspakrama in terms of structural aspects,

3) Moral values in the oral tradition of Bekesah Puspakrama viewed from the semiotic aspect.

The oral tradition of Bekesah Puspakarma on the Sasak community needs to consider three important things namely methods, techniques and data analysis. While the way of inheritance, the pattern of oral tradition presentation Bekesah Puspakarma in this study was not discussed. Because in this research focused on structural and semiotic study. The matters to be discussed in the dissertation methodology of this research is something that relates to several important things such as the specific objectives of research, place and time of research, research background, research methods, data collection procedures, data recording, data analysis, checking the validity of data, and research steps. Therefore, a comprehensive start from the planning activities, implementation until the end of research activities.

\section{Findings}

Description of the results of the analysis of findings about the oral tradition of Bekesah Puspakrama is based on structural and semiotic approach, in principle based on the text structure associated with the socio-cultural situation of the Sasak 
people who are the background of the Puspakrama text. Regarding the structure and semiotic in the text has been done by many experts. In an effort to expose the structure and semiotics of the Bekesah Puspakrama text, Levis-Strauss and Pierce's views are used. Strauss divides the story-forming elms into an event relation in the story in a text called a relation while Pierce shares the meaning relationship contained in the text based on the sign, icon, symbol, and index.

The discussion of moral values in the Bekesah Puspakra$m a$ text is a sub-focus and a discussion of the findings in this study. Moral values are subjective depending on the point of view and convention that has become the measuring value of human behavior that is considered reasonable and logical as presented by Kasttsoff. Overall text on Bekesah Puspakrama script consisting of 533 verses of song and 152 pages. After carrying out the process of observation, verification, and identification of the manuscript. The current researchers conducted the process of analysis and interpretation of the text so that the authors found 230 verses of song containing moral values that are divided into three stages.

First is the values associated with the moral aspect as many as 146 related to God, as much as 16 stanza of song moral values of human self against humans, and fellow creatures as many as 91 verses of song, moral values of human self against nature and environment as much as 15 pieces of song and value moral self-human to the nation and Country as much as 23 pieces of song as data.

The second is a structural approach in manuscripts and finds 54 stanzas of song which are divided into (1) The relationship of blood and kinship amounts to 8 verses of song, (2) The relationship of idealism and the nations are 14 stanza of song, (3) Inner conflicts, struggles and allied wars consisted of 16 verses of the song, and (4) The clarification and completion of 16 stanzas of song.

Third is the moral value with semiotic approach consisting of 30 stanza of songs that have a cultural significance in the Sasak community which is divided into Agape or divinity that consisted of 5 song data, Storge is 5 song data, Eros is 3 song data, Phileo consisted of 9 song data, Narcissistic consisted of 2 song data, Cosmic consisted of 3 song data, and Patriotic consisted of 4 song data.

The oral tradition of Bekesah Puspakrama does not mention the identity of its author, but the author mentions the script writing on Saturday, $9^{\text {th }}$ of Jumadilawal -7 Rajab 1335 Hijri$a h$. The existence of texts of words or phrases and an understanding of the contents of the songs in the text may influence the findings and the findings of the concepts of moral values that will be explained in the discussion in detail in research with the title "Moral Values in Oral Tradition of Bekesah Puspakrama at the Sasak Community in the West Nusa Tenggara.

\section{DISCUSSION}

Analyzing the moral values of the oral tradition of Bekesah Puspakrama in the Sasak community consists of 230 verses of the song aims to derive deep meaning, whether hidden or meaningful in the oral tradition of Bekesah Puspakrama. Analyzing a text in a script is an attempt to give meaning.
Text on oral tradition of Bekesah Puspakrama is a structure because it has a sign system and there is a meaning with the medium of language that is Jejawen or Sasak fine. Each language in the manuscript has a semiotic system or signs that show signs and denote the conventions of cultural-based moral values depicted in the text. The theory applied in the analysis is Levi-Strauss is a model of thinking of relationships, the relationship of the text with the things of mythology, while the semiotic theory uses Pierce thinking model, because words, sentences, are signs, icons, indexes and symbols, with moral values. As an example:

\section{Moral Values in Oral Tradition of Bekesah Puspakrama}

\section{Human Moral Values of God}

Tatkalane Sanicara, tigang sanga pananggale, Jumadiran mlah anemwa, kang ucapan Jrat Nabya, srIbu kang tigang ngatus, tigang puluh kang lalima.

Meaning: Saturday, three and nine dates, in the month of Jumadilawal, at the Prophet's Hijrah, one thousand three hundred, thirty-five. (Asmarandana 1)

The quotation above, we can take the moral teaching that every time we start our conversation as a human being, especially as a Muslim, should be disciplined in many ways, whether in speaking or writing. In addition to the form of ethics, as a writer will get the benefits as a writer. The writing of Islamic date and year data is part of the writer's identity or style of language with a specific purpose both the function and usefulness of writing in the community for the reader. The style of language is a way of expressing thoughts both spoken and written or an author's identity like Hartoko and Rahrmanto's opinion in (Pradopo 2009: 266) in the previous chapter that style is the way of pronouncing the language in prose or how the author expresses something to be said.

Pernahe Kamasan ika, ing Betalmukdas rekeki Artinya: Tempat Kamasan itu, di negeri Betalmukdas (Puh sinom, 7)

The above quotation is the teaching of moral values about the relationship of man with God. The country of Betalmukdas is a term from a holy place, which is found in man, so must be careful, keep and use it, so as to avoid what is forbidden by God. Betalmukdas interpreted as part of the secret of God that is in pubic son of Adam. In the view of the classical tariqah and philosophy the Sasak community is explained that "in the nutfah there is semen, in the mani there is madi, in madi there is manikem, in manikem there is a secret, in the secret there I am". I am here interpreted as God.

\section{Structural and Semiotic Approach}

\section{Structural approach}

Literary works are created by language. The presence of traits, shapes, and contents. The existence of literary texts is a representation of the reality and cultural patterns of a society, from which literature was born or created. Structuralism is present to complement the expressive and historical literature, ethnographic research. The structuralism approach is an approach that began to be recognized and developed in France in the 1950s of the Ferdinal de Saussure linguistic thought. The ba- 
sic principle of structuralism is that the universe occurs from a relation (forma) rather than an object (substantial). Saussure considers the general phenomenon of language to always have two sides, namely Parole (sepeech, the use of language) and Langue (language system common language group (Saussure in Toum, 2011: 163), meaning that structuralism can be understood in a way so the researcher understands thoroughly.In structuralism, it is explained that language consists of inseparable forms and meanings, no matter how small the change in the word, its meaning or its marker will change.

The main purpose of structural analysis is to dismantle and expound as carefully as possible the interrelation and interconnection of all aspects of literary work together to produce a comprehensive meaning (Teeuw, 1988: 120). Therefore literary work is a structure of slavery that is no exception to the literary text in the form of poetry, so to understand the meaning of poetry using structural study which cannot be separated by the study of semiotics that examines the signs. While LeviStraus paid special attention to the myth, which he thought had logical quality rather than psychological, or religious. He sees myth as the language, a narrative already told to be known.

Strauss suggests writing index cards that are numbered according to the order of the story. Each index card number indicates a subject that performs a particular function. The same relationship will emerge diachronically, mytheme must be synchronized and diachronic, pragmatic and syntagmatic (Toum, 2011: 175-176). Myth has its own grammar. To see the mythical grammar according to Strauss needed the following two steps:

1) Finding mytheme is the smallest element in the mystical discourse, which are the operational, relative and negative units.

2) Develop mytheme; syntagmatic and paradigmatic after found a variety of mytheme, it is the sentences that indicate certain relationships that exist in a or a few myths by having an index that is an object perform a certain function called a relation.

Furthermore, the theory and method of Levi Strauss' study will be applied in this study, by examining Bekesah Puspakrama texts on Sasak communities in West Nusa Tenggara. As is done with the subsequent structural analysis by dividing the story in episodes, the goal is to classify the parts and scenes narrated in a story.

\section{Semiotic Review}

The term semiotics or semiotics, arose in the late $19^{\text {th }}$ century, by the American pragmatic school philosopher Charles Sander Peirce, referring to the formal doctrine of signs (Sobur, 2013: 13) is a semiotic that considers the social phenomenon (society) and culture as a sign of semiotic theory. Semiotics also studies the systems, rules, conventions that allow them to have meaning (Ratih, 2016: 1).

Given the fact that nature is inseparable from the sign, the human mind is constituted by the concept of signs so as to be able to relate to reality. the language itself is a sign system, and sign is the unity between two inseparable aspects of each other, namely signified and signifier. Signified is a material aspect of language which means when in verbal communication is said and what is heard, and if in text form it will relate to what is written and read or polysemic. While signifier includes the sign itself or what is signified or an isotope. Signified and Signifier is a unity.

\section{CONCLUSION}

A society customs and traditions cannot be interfered by traditions of other groups, especially external cultures, due to belief in the concept of life, values in different customs. In addition, the tradition is a heritage of its predecessor, so that each individual in the group of the society's traditions is obliged to preserve and preserve, especially the succeeding generations in various joints of life. Bekesah Puspakrama contains very high moral values and philosophical for the Sasak community in West Nusa Tenggara. Moral values contained in it about the value of God, the greatness of God and the creation of a mystical. The moral value of the self against God amounts to 17 verses of the song, the value of humanity and the fellow creatures as many as 91 verses of song, the moral values associated with the environment amounted to 15 verses of song, moral values associated with the nationality as many as 23 verses of song.

The main purpose of this research is to find and understand the moral values contained in the Bekesah Puspakrama text found in the Sasak community in West Nusa Tenggara in accordance with the methods and approaches used in the research so that it can be a treasure for knowledge, especially the study of oral tradition.

Suggestion and recommendations of the writer are for 1) Teachers, especially teaching about Bekesah texts are very useful in the world of education in schools as well as in universities, especially the Faculty of Letters and study programs Indonesian and local education. 2) West Nusa Tenggara Regional Government, 3) Artists, Culturalists, and Researchers with the study of oral tradition especially oral traditions Sasak community should revitalize and lift Bekesah on texts which are similar to the Bekesah Puspakrama script for the development of knowledge and the formation of good character in society.

\section{REFERENCES}

Danandjaya, J. (2015). Metodologi Kajian Tradisi Lisan. Jakrata: Buku Obor. Yayasan Pustaka Obor Indonesia.

Djojosuroto, K. (2006). Analisis Teks Sastra dan Pengajarannya.Yogyakarta: Pustaka

Duranti. (1997). Linguistic Anthropology. Cambridge: University press.

Edwards, P. (2002). Encyclopedia of philosophy. London: MacMillan Publisher

Emzir, D., \& Saefur, R. (2015). Teori Pengajaran Sastra. Jakarta: PT. Raja Grafindo Persada.

Pradopo, R.D. (2009) Pengkajian Puisi. Yogyakarta: Gajah Mada University Press

Rachels, J. (2004). Filsafat Moral, Yogyakarta: Kanisius.

Rahmat, A. (2013). Filsafat Ilmu Lanjutan. Jakarta: Kencana Prenada Media Group. 
Ratih, R. (2016). Teori dan Aplikasi Semiotik Michael Riffatrerre. Yogyakarta: Pustaka Pelajar.

Sobur, A. (2013). Semiotika Komunikasi. Bandung: PT. Remaja Rosdakarya.

Suryani \& Elis, N.S. (2012). Filologi. Bogor: Penerbit Ghalia Indonesia.
Teeuw, A. (1988).Sastra dan Ilmu Satra, Teori pengantar Sastra.Jakarta: Pustaka Jaya

Toum, Y.Y. (2011). Studi Sastra Lisan; Sejarah, teori, Metode dan Pendekatan Disertai Contoh Penerapannya. Yogyakarta: Halmahera. 